Historic, Archive Document

Do not assume content reflects current scientific knowledge, policies, or practices. 
$25 P 11$
$R 23$

CAt/sts

A Cooperative Education

\section{Experience with}

the

\section{Forest Service in Alaska}



USDA Forest Service, Chugach National Forest

United States Department of Agriculture

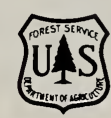

Forest Service Alaska Region MB-R10-169 
Cooperative Education (Coop-Ed) is a unique educational program for high school and college students, which combines academic study with periods of study-related employment. The program provides a realistic exposure to Forest Service career opportunities and the work environment. It exposes the student to a variety of people, places, and situations.

\section{The Coop-Ed program offers the following opportunities:}

- High school diploma program;

- Undergraduate certificate of diploma program of at least one academic year, as part of an accredited college-level, technical, trade, vocational or business school curriculum;

- Associate degree program of at least two academic years;

- Baccalaureate degree program; and

- Graduate or professional degree program.

Students are paid for the work portions of the program.

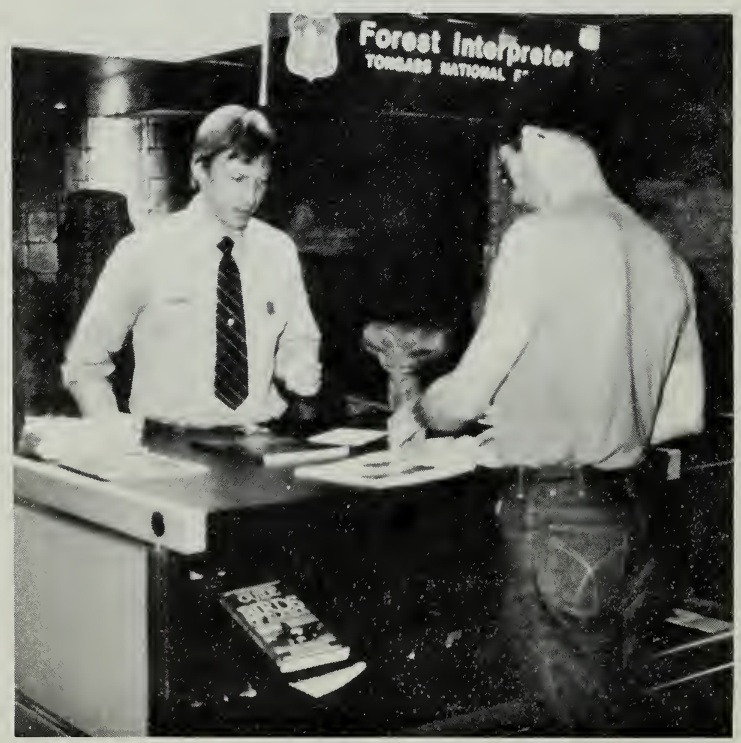

Shipboard forest interpreters provide information to travelers from around the world.

\section{What the Forest Service does}

The Forest Service, U.S. Department of Agriculture, has the Federal responsibility to protect, improve, and wisely use the Nation's forest and range resources for multiple purposes. This includes top level participation in setting national policies that relate to humans and their natural environment.

The Alaska Region is concerned with the resources in the National Forest System, including timber, wildlife, fish, air, water, soil, recreation amenities, and minerals. It takes a wide variety of specialists to maximize the benefits of the national forests. The Region relies on long-range program planning to assure that the resource demands placed on its Federal lands are met, and the productivity and environmental quality of these lands are maintained.

\section{Eligibility Requirements}

To apply for the Coop-Ed Program, students must meet the following:

- Be at least 16 years old.

- Be a United States citizen or a national. In the absence of qualified citizens, a student may participate if they are legally admitted to the United States as a permanent resident, and are able to meet citizenship requirements prior to becoming a career Forest Service employee.

- Meet security and fitness requirements.

- Be enrolled in a qualifying educational institution and recommended by the school's Cooperative Education Program.

- Be in good academic standing.

- Be taking a course of study or have career goals related to the position. 


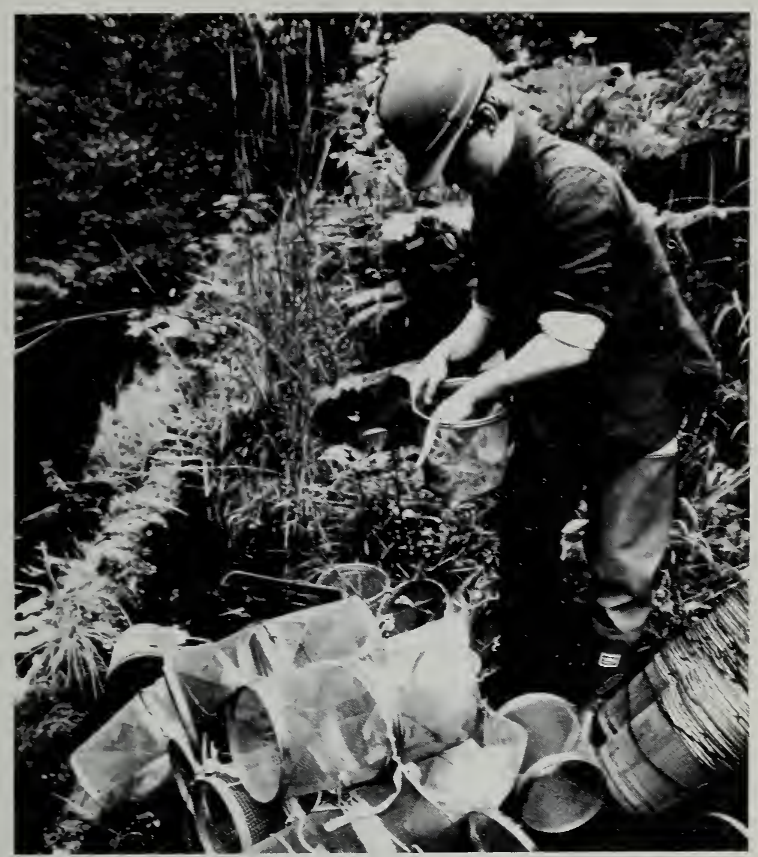

Forest Service fish biologist prepares fish traps to sample stream populations.

\section{Type of Positions Available}

In the Alaska Region, the majority of Coop-Ed positions are filled by students in forestry, wildlife/fisheries biology, and engineering disciplines. Occasionally students are hired in other natural resource fields, i.e., archaeology, soils, landscape architecture, geology. Appointments are also made in the fields of computers, accounting, and general business management. The Region fills an average of 5 to 15 positions each year depending on forecasted budgets.

\section{How to Apply for Positions}

Students must be recommended by appropriate staff at their school. Positions for college co-ops are advertised in January or February of each year at colleges from which recruitment is done. Include with the recommendation your SF-171 application, and a copy of transcripts. Applications are also 


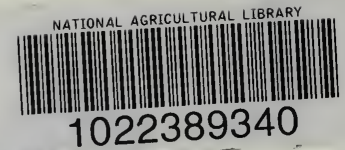

acceptable from stud attending other colleges or univers during this time period. College Cooperati Education Coordinators can tell students whether or not the Alaska Region recruits from their particular college. High school students should contact the Coop-Ed Coordinator at their school for information.

\section{Salary and other Benefits}

Students receive the following benefits:

- Pay in accordance with the current Federal pay scale, which can range from GS-1 to GS-4 for undergraduate or below and GS-5 to GS-9 for graduate programs, depending on the applicant's year in school and their experience. In addition, Federal employees in Alaska receive a cost of living allowance of 25 percent of their annual base salary. Employees receive paychecks every two weeks.

- Opportunity to compete for tuition assistance

- Sick and annual (vacation) leave

- Paid holidays

- Retirement

- Option for health and life insurance benefits

- Opportunity for a permanent position upon graduation and completion of the Cooperative Education Program

\section{When a Student is Selected}

Upon selection, Coop-Ed students accept the responsibility to:

- Maintain good academic standing.

- Complete two work periods for the Forest Service totaling 1040 hours (26 weeks) for the baccalaureate and associate degree programs. This may be during the summer but must also include a work period during the school year. For the high school and graduate program, there must be at least one period of 640 hours (16 weeks).

- Maintain a satisfactory level of performance during the work periods.

\section{When a Student is Converted to a Career Conditional Appointment}

Students are eligible for non-competitive conversion within 120 calendar days once they receive their degree; have completed all of their work period requirements; meet U.S. citizenship requirements; and are recommended for conversion by their work supervisor.

\section{Send Application to, or for more Information, Contact}

\author{
Alaska Region Forest Service \\ Cooperative Education Coordinator \\ P. O. Box 21628 \\ Juneau, AK 99802-1628 \\ (907) 586-8858
}

\section{National Forest Locations}

Tongass National Forest - Ketchikan Area, Ketchikan, AK

Tongass National Forest - Stikine Area, Petersburg, AK

Tongass National Forest - Chatham Area, Sitka, AK

Chugach National Forest - Anchorage, AK

Candidates will be considered without discrimination for any non-merit reason such as race, religion, sex, national origin, politics, marital status, disability, age, or membership or nonmembership. 